\title{
Studies on Effect of Chemicals on Shoot Growth Success of Cuttings in Passion Fruit (Passiflora edulis Sims)
}

\author{
R.N. Parse ${ }^{1 *}$, S.B. Mane ${ }^{2}$ and U.M. Naglot ${ }^{3}$ \\ ${ }^{1}$ College of Agriculture, Badnapur, ${ }^{3}$ College of Agriculture, Badnapur, Vasantrao Naik \\ Marathwada Krishi Vidyapeeth Parbhani, Maharashtra, India \\ ${ }^{2}$ College of Agriculture Dr. Balasaheb Sawant Konkan Krishi Vidyapeeth, Dapoli, \\ Maharashtra, India \\ *Corresponding author
}

\begin{tabular}{l} 
Key w o r d s \\
$\begin{array}{l}\text { Cutting, Passion } \\
\text { fruit, Root, Shoot, } \\
\text { Leaf area }\end{array}$ \\
Article Info \\
$\begin{array}{l}\text { Accepted: } \\
20 \text { August } 2018 \\
\text { Available Online: } \\
10 \text { September } 2018\end{array}$ \\
\hline
\end{tabular}

\section{A B S T R A C T}

The present investigation entitled "Studies on effect of chemicals on success of cuttings in passion fruit (Passiflora edulis Sims)" was carried out at the Instructional Cum Research Farm, Department of Horticulture, College of Agriculture, Badnapur during the year 20152016. The experiment was laid out in Randomized Block Design with thirteen treatments replicated thrice, comprising three treatments of IBA concentrations i.e. (500, 750 and $1000 \mathrm{ppm}$ ), three treatments of NAA concentration i.e. (500, 750 and $1000 \mathrm{ppm})$, three treatments of Salicylic acid concentration i.e. $(1500,2000$ and $2500 \mathrm{ppm})$, three treatments of Ethanol concentration i.e. (10, 30 and $50 \%$ ) and control. The results of present study indicated significant differences with shoot and root growth observations viz., number of shoots per cuttings (7.33), shoot diameter $(1.97 \mathrm{~cm})$, number of leaves per cuttings (5.20), leaf area $\left(24.92 \mathrm{~cm}^{2}\right)$ superior in treatment $\mathrm{T}_{1}$ (IBA $500 \mathrm{ppm}$ ). However, in treatment $\mathrm{T}_{3}$ (IBA $1000 \mathrm{ppm}$ ) days taken for sprouting (3.77days), number of sprouted cuttings $(45.34 \%)$, shoot thickness $(1.76 \mathrm{~cm})$, shoot length $(30.00 \mathrm{~cm})$, number of leaves per cuttings (5.10), leaf area $\left(23.83 \mathrm{~cm}^{2}\right)$ was observed significantly better. Application of chemical treatment viz., passion fruit cuttings dipping in IBA $1000 \mathrm{ppm}$ solution, $1-2 \mathrm{~cm}$ (at the lower portion) for 3-5 seconds to be beneficial for maximum growth and survival percentage.

\section{Introduction}

Passion fruit (Passiflora edulis Sims) is belongs to family Passifloraceae is a native to the warmer moist regions of the rainforest in the Amazon region of Brazil and possibly in Paraguay and northern Argentina. It is a perennial, vigorous, climbing, woody vine.
The purple passion fruit (Passiflora edulis var. edulis Sims) is adapted to subtropics or at higher altitudes in the tropics. Passion vines prefer a slightly acid soil. The name "passion fruit" is not derived from any aphrodisiac quality of the fruit but, named reportedly, by Spanish Catholic missionaries who saw in the flower, the symbolism of the Passion of Christ 
where "Passus" means "Suffering" and "flos" means "flower". Passion fruit should more correctly be referred to as the passion flower fruit, but the trade more commonly uses passion fruit. Passion fruit is known in Hawaii as Lilikoi, golden passion fruit in Australia, maracuja peroba in Brazil and yellow granadilla in South Africa.

A vigorous perennial vine has a trilobed leaves with finally toothed margins which bears egg shaped yellow or purple fruit. The fruit is rich in vitamin A and Vitamin C. There are two recognized forms of edible passion fruit; purple (Passiflora edulis Sims.) and Yellow (Passiflora edulis flavicarpa Deg.). The purple passion fruit is originally native of Tropical America; a yellow passion fruit is being considered as a mutation of the purple variety or as a natural hybrid between purple and another related species of passion fruit. Passiflora quadrangularis L., the giant granadilla is also cultivated to a limited extent for local consumption. It grows best in a hot, moist climate and produces a round or oblong, pale yellow to yellowish -green fruit when ripe, which may reach up to 8 inches in size. Passilflora foetida L., a wild species, bears very small fruits and has unique characters of being highly precocious and very short fruit maturity period. Purple and yellow are commonly cultivated in northeast region of India, while Kavery (hybrid between purple and yellow) is common in south India.

In Maharashtra state passion fruit crops grown on very minor or rare plantation. Passion fruit crops treated as minor or other fruit crop which includes almond, aonla, ber, custard apple, jackfruit, kiwifruit, peach, pear, plum, walnut etc. which grown on area about 4.18 lakh ha with production is 12.00 lakh MT and productivity is $2.87 \mathrm{MT} / \mathrm{ha}$ (Anon, 2014). In India, passion fruit grows wild in the Nilgiris, Wyanad, Kodaikanal, Coorg, Malabar, Nagaland, Mizoram and Manipur. Recently, its commercial cultivation has been extended into most part of Manipur. The passion fruit is becoming as one of the most important fruit crops in the North-Eastern states of India (Chadha, 2002). The passion fruit can be propagated through sexual or asexual. The sexual propagation is commercially most widely used, although the grafting methods and cuttings are quite promising for its cultivation (Sanjose, 1994). The passion fruit propagation by cuttings, it has allowed obtaining and multiplication production plants, tolerant to pests, diseases and homogenous, these features of great interest of great for the production of rootstocks (Lima and Cunha, 2001). The species under study can be used a rootstock for $P$. alata and $P$. quadrangularis because tolerates low temperature $\left(5^{\circ} \mathrm{C}\right)$. Due to climatic conditions of the state of Parana, where frosts usually occur, it is of great importance to preserve and domestic this species, much appreciated by animals and exploited to food (Vanderplank, 1996).

\section{Materials and Methods}

The experiment entitled, "studies on effect of chemicals on success and survival of cuttings in passion fruit (Passiflora edulis Sims)" was conducted at Instructional Cum Research Farm, Department of Horticulture, College of Agriculture, Badnapur during the year 20152016. The cuttings of passion fruit used for this research were selected from 8 years old mother plant. Semi hardwood types of cutting were carefully selected. The cuttings will soaked in different concentrations of chemicals like Indole Butyric Acid (500, 750, 1000 ppm), Naphthalene Acetic Acid (500, 750, 1000 ppm), Salicylic Acid (1500, 2000, $2500 \mathrm{ppm})$, Ethanol (10, 30, $50 \%)$ and Control. The lower portion of cuttings (1-2 $\mathrm{cm})$ was be treated with different concentration of chemicals by quick dip method for 3-5 seconds and allow to dry for 5 
minutes in partial shed and then planted in poly bags containing soil + sand + FYM $(1: 1: 1)$ in a such manner that the $1 / 3^{\text {rd }}$ portion of the cutting insert in the media and light irrigation was applied gradually in the morning and evening with the help of water can.

\section{Results and Discussion}

The present investigation entitled "Studies on effect of chemicals on success and survival of cuttings in passion fruit (Passiflora edulis Sims)" was carried out during 2015-2016 at Instructional Cum Research Farm, Department of Horticulture, Badnapur, Dist. Jalna. The observations were recorded on various aspects viz., days required for sprouting, number of shooted cuttings, number of shoots per cuttings, shoot diameter, shoot length, number of leaves per cuttings, leaf area, fresh weight of shoot, dry weight of shoot, length of root, diameter of root, fresh weight of root, dry weight of root, final survival percentage of cuttings. The all above observations are presented in table 1 .

The minimum days (3.7days) taken for sprouting of cuttings was observed in $\mathrm{T}_{3}$ (IBA $1000 \mathrm{ppm})$, however it was at par with the $\mathrm{T}_{1}$ (4.4 days), $\mathrm{T}_{2}$ (3.8 days) and $\mathrm{T}_{6}$ (4.7 days) and are significantly superior over rest of the treatments. Maximum days (7.9 days) taken for sprouting of cuttings was observed in control i.e. $\mathrm{T}_{13}$. The number of sprouted cuttings at 90 days data presented in Table 1 revealed that, maximum number of sprouted cuttings $(7.91 \%)$ was observed in treatment $\mathrm{T}_{3}$ (IBA 1000 ppm).Which, were significantly superior over rest of the treatments. While, minimum number of sprouted cuttings $(3.60 \%)$ was observed in control i.e. $\mathrm{T}_{13}$.

The number of shoots per cutting at 90 days data presented in Table 1 revealed that, maximum number of shoots per cuttings (7.33) was observed in treatment $\mathrm{T}_{1}$ (IBA 500 ppm). Which were significantly superior over rest of the treatments. While, minimum number of shoots per cuttings (1.00) was observed in control i.e. $\mathrm{T}_{13}$.

Maximum shoot thickness of cuttings at 90 days data presented in Table 1 revealed that, maximum shoot thickness of cutting $(1.97 \mathrm{~cm})$ was observed in treatment $\mathrm{T}_{1}$ (IBA $500 \mathrm{ppm}$ ) and it was at par with $\mathrm{T}_{4}(1.62 \mathrm{~cm}), \mathrm{T}_{3}(1.76$ $\mathrm{cm})$ and $\mathrm{T}_{2}(1.87 \mathrm{~cm})$. Which were significantly superior over the treatment $\mathrm{T}_{9}$, $\mathrm{T}_{10}, \mathrm{~T}_{11}, \mathrm{~T}_{12}$ and $\mathrm{T}_{13}$. While, minimum shoot thickness of cutting $(0.89 \mathrm{~cm})$ was observed in control i.e. $\mathrm{T}_{13}$.

The highest shoot length per cutting at 90 days data presented in Table 1 revealed that, maximum shoot length $(30.00 \mathrm{~cm})$ was observed in treatment $\mathrm{T}_{3}$ (IBA $1000 \mathrm{ppm}$ ) and it was at par with the treatment $\mathrm{T}_{2}(28.33 \mathrm{~cm})$.

Which was significantly superior over rest of the treatments. While, minimum shoot length per cutting $(11.50 \mathrm{~cm})$ was observed in control i.e. $\mathrm{T}_{13}$.

Maximum number of leaves per cutting at 90 days data presented in Table 1 revealed that, maximum number of leaves (5.50) was found in treatment $\mathrm{T}_{2}$ (IBA $750 \mathrm{ppm}$ ) and it was at par with $\mathrm{T}_{5}$ (4.65), $\mathrm{T}_{3}$ (5.10) and $\mathrm{T}_{1}(5.20)$ and significantly superior over rest of the treatments. While, minimum number of leaves per cutting (4.00) was found in control.

The leaf area per cuttings at 90 days data presented in Table 1 revealed that, maximum leaf area per cutting $\left(24.92 \mathrm{~cm}^{2}\right)$ was observed in treatment $\mathrm{T}_{1}$ (IBA $500 \mathrm{ppm}$ ) and it was at par with $\mathrm{T}_{5}\left(22.02 \mathrm{~cm}^{2}\right), \mathrm{T}_{4}\left(22.80 \mathrm{~cm}^{2}\right), \mathrm{T}_{3}$ $\left(23.83 \mathrm{~cm}^{2}\right)$ and $\mathrm{T}_{2}\left(24.45 \mathrm{~cm}^{2}\right)$ and significantly superior over rest of the treatments. While, minimum leaf area per cutting $\left(14.70 \mathrm{~cm}^{2}\right)$ was observed in control (Fig. 1 and 2). 
Int.J.Curr.Microbiol.App.Sci (2018) 7(9): 3145-3151

Table.1 Effect of chemicals on success of cuttings in passion fruit

\begin{tabular}{|c|c|c|c|c|c|c|c|}
\hline Tr. & $\begin{array}{l}\text { Days to } \\
\text { sprouting }\end{array}$ & $\begin{array}{l}\text { No. of } \\
\text { shooted } \\
\text { cuttings } \\
(\%)\end{array}$ & $\begin{array}{l}\text { No. of } \\
\text { shoots per } \\
\text { cuttings }\end{array}$ & \begin{tabular}{|l|} 
Shoot \\
diamete \\
$\mathrm{r}(\mathrm{cm})$
\end{tabular} & $\begin{array}{l}\text { Shoot } \\
\text { length } \\
(\mathrm{cm})\end{array}$ & $\begin{array}{lr}\text { No. of } \\
\text { leaves per } \\
\text { cutting }\end{array}$ & $\begin{array}{l}\text { Leaf area } \\
\left(\mathrm{cm}^{2}\right)\end{array}$ \\
\hline $\mathbf{T}_{1}$ & 4.4 & $\begin{array}{l}6.40 \\
(36.69)\end{array}$ & 7.33 & 1.97 & 24.43 & 5.20 & 24.92 \\
\hline$T_{2}$ & 3.8 & $\begin{array}{l}6.80 \\
(38.98)\end{array}$ & 4.60 & 1.87 & 28.33 & 5.50 & 24.45 \\
\hline$T_{3}$ & 3.7 & $\begin{array}{l}7.91 \\
(45.34)\end{array}$ & 5.00 & 1.76 & 30.00 & 5.10 & 23.83 \\
\hline$T_{4}$ & 5.2 & $\begin{array}{l}5.82 \\
(33.34)\end{array}$ & 4.30 & 1.62 & 19.00 & 4.42 & 22.80 \\
\hline$T_{5}$ & 4.9 & $\begin{array}{l}5.90 \\
(33.82)\end{array}$ & 3.17 & 1.52 & 20.00 & 4.65 & 22.02 \\
\hline$T_{6}$ & 4.7 & $\begin{array}{l}6.20 \\
(35.54)\end{array}$ & 3.83 & 1.35 & 25.30 & 4.36 & 20.03 \\
\hline$\overline{T_{7}}$ & 5.6 & $\begin{array}{l}5.20 \\
(29.80)\end{array}$ & 2.60 & 1.27 & 18.30 & 4.25 & 19.37 \\
\hline $\mathrm{T}_{8}$ & 5.7 & $\begin{array}{l}5.60 \\
(32.09)\end{array}$ & 2.47 & 1.23 & 18.90 & 4.26 & 18.90 \\
\hline$T_{9}$ & 5.9 & $\begin{array}{l}4.90 \\
(28.08)\end{array}$ & 3.00 & 1.15 & 16.30 & 4.18 & 18.37 \\
\hline$T_{10}$ & 6.1 & $\begin{array}{l}4.70 \\
(26.93)\end{array}$ & 1.40 & 1.13 & 15.50 & 4.05 & 17.85 \\
\hline $\mathrm{T}_{11}$ & 6.4 & $\begin{array}{l}4.40 \\
(25.21)\end{array}$ & 1.80 & 1.07 & 14.00 & 4.10 & 17.45 \\
\hline$T_{12}$ & 6.8 & $\begin{array}{l}3.97 \\
(22.73)\end{array}$ & 1.97 & 0.96 & 13.66 & 4.01 & 15.40 \\
\hline$T_{13}$ & 7.9 & $\begin{array}{l}3.60 \\
(20.62)\end{array}$ & 1.00 & 0.89 & 11.50 & 4.00 & 14.70 \\
\hline $\mathrm{SE} \pm$ & 0.33 & 0.18 & 0.31 & 0.14 & 1.25 & 0.35 & 1.37 \\
\hline $\begin{array}{l}\text { CD at } 5 \\
\%\end{array}$ & 0.96 & 0.53 & 0.93 & 0.42 & 3.64 & 1.03 & 4.01 \\
\hline
\end{tabular}




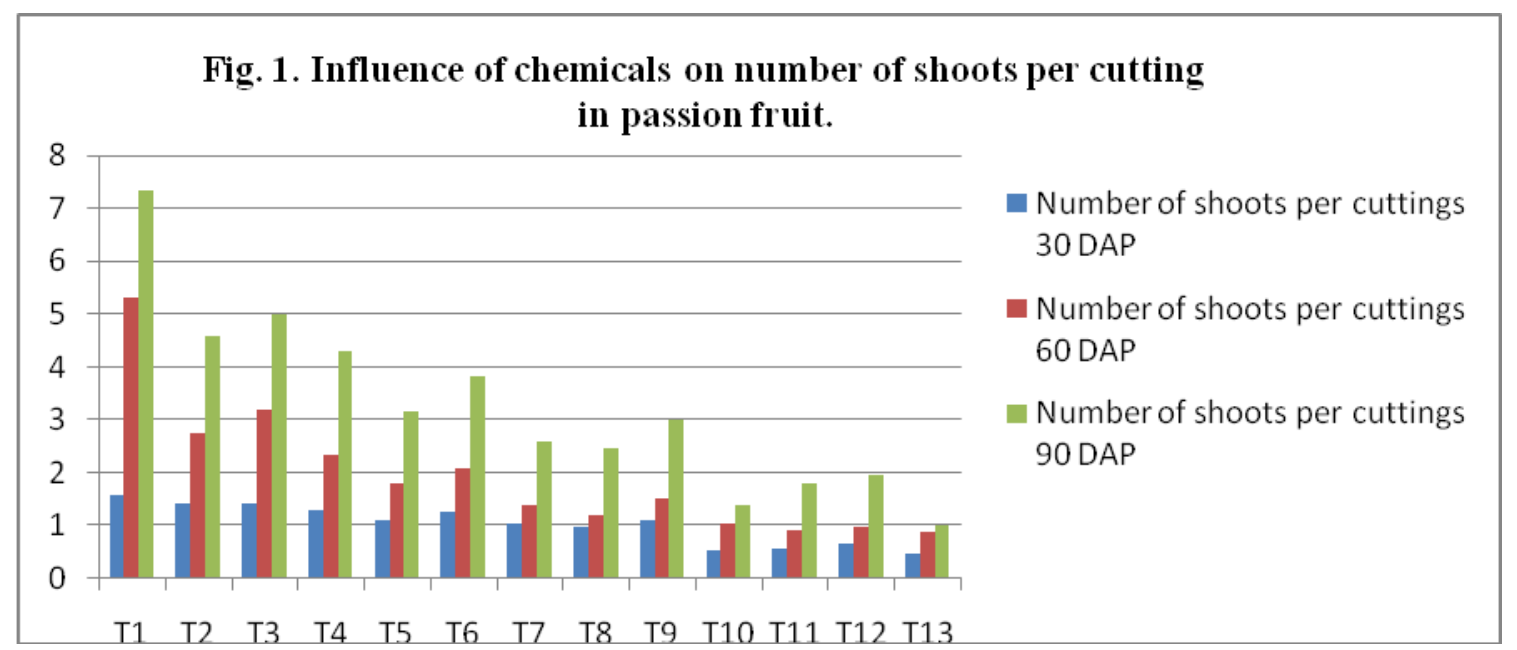

Fig. 2. Influence of chemicals on shoot length in passion fruit.

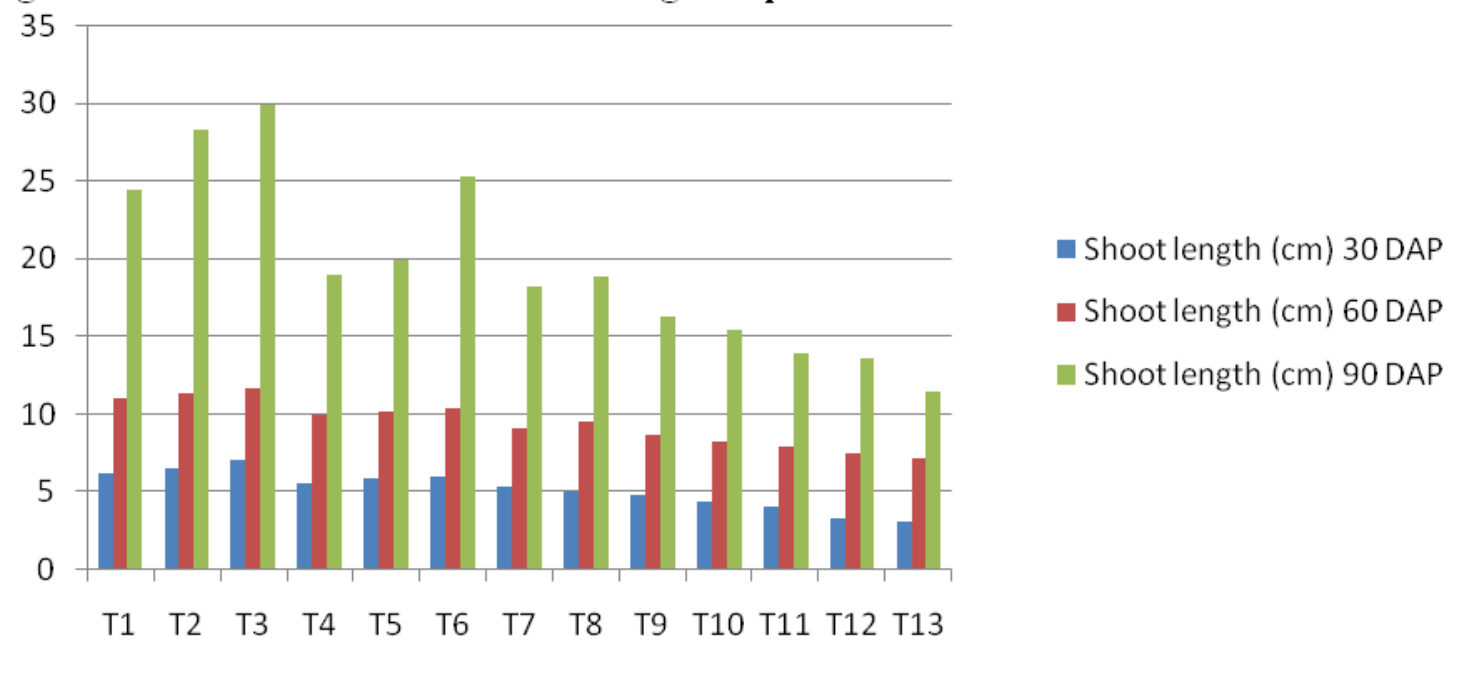

The experiment entitled "Studies on Effect of chemicals on success and survival of cuttings in passion fruit (Passiflora edulis Sims)" was carried out during 2015-16. The objectives framed were concentrated to study the effect of chemicals on survival and better growth of cuttings in passion fruit.

The minimum days (3.77 days) taken for sprouting of cuttings was observed in $\mathrm{T}_{3}$ (IBA $1000 \mathrm{ppm}$ ), however it was at par with the $\mathrm{T}_{1}$ (4.4 days), $\mathrm{T}_{2}$ (3.8 days) and $\mathrm{T}_{6}$ (4.7 days) and significantly superior over maximum days (7.9 days) taken for sprouting of cuttings was observed in control i.e. $\mathrm{T}_{13}$. This might due to fact that root formation process in cuttings is intensified by IBA through polysaccharide hydrolysis, which provides energy for meristematic tissues and thereby for root primordial for roots formation (Sivaji Thota et al., 2014). Similar results were reported by Sukhjit Kaur (2015) in peach.

The number of sprouted cuttings at 90 DAP was maximum $(45.34 \%)$ in treatment $\mathrm{T}_{3}$ (IBA $1000 \mathrm{ppm}$ ), which were significantly superior over rest of the treatments. While, minimum number of sprouted cuttings $(20.62 \%)$ was observed in control i.e. $\mathrm{T}_{13}$. IBA would be effective for root initiation, sprout growth and 
ultimate survival of rooted cuttings of kagzi lime. An overall situation lead to the conclusion that, IBA at higher concentration possesses more potential in the development of roots, sprouting and decreases the mortality percentage that the control and lower concentration of IBA (Manan et al., 2002). Similar results were reported by Manan et al., (2002) in guava and Diwaker and katiyar (2013) in Kagzi lime.

The number of shoots per cutting (7.33) at 90 DAP was maximum in treatment $\mathrm{T}_{1}$ (IBA 500 ppm), which were significantly superior over rest of the treatments. While, minimum number of shoots per cuttings (1.00) was observed in control i.e. $\mathrm{T}_{13}$. Similar results the interaction of the various chemical treatments according to the environmental conditions is strongly linked and may reflect different results when these conditions are altered (humidity, temperature, substrate, physiological condition of each species among others). The results are in agreement with the findings reported by Pires et al., (2010) in passion fruit.

Maximum shoot diameter per cuttings at 90 DAP $(1.97 \mathrm{~cm})$ was observed in treatment $T_{1}$ (IBA $500 \mathrm{ppm}$ ), however it was at par with $\mathrm{T}_{4}$ $(1.62 \mathrm{~cm}), \mathrm{T}_{3}(1.76 \mathrm{~cm})$ and $\mathrm{T}_{2}(1.87$ $\mathrm{cm})$. Which were significantly superior over the $\mathrm{T}_{9}, \mathrm{~T}_{10}, \mathrm{~T}_{11}, \mathrm{~T}_{12}$ and $\mathrm{T}_{13}$ treatments. While, minimum shoot thickness per cutting $(0.89 \mathrm{~cm})$ was observed in control. IBA was found to be better as compare to NAA, Salicylic acid and Ethanol concentration with respect to achieving better success and producing better vegetative growth, while among the different growing conditions planting of cuttings. Similar results were reported by Ram et al., (2005) in pomegranate and Bhatt \& Bhatt (2014) in Kagzi lime.

Maximum shoot length per cutting $(30.00 \mathrm{~cm})$ at 90 DAP was observed in treatment $\mathrm{T}_{3}$ (IBA
$1000 \mathrm{ppm}$ ), however it was at par with the treatments $\mathrm{T}_{2}(28.33 \mathrm{~cm})$ and significantly superior over rest of the treatments. While, minimum shoot length per cutting $(11.50 \mathrm{~cm})$ was observed in control i.e. $\mathrm{T}_{13}$. Similar results were reported by Manan et al., (2002) in guava.

Maximum number of leaves per cutting (5.50) at 90 DAP was found in treatment $\mathrm{T}_{2}$ (IBA $750 \mathrm{ppm})$, however it was at par with $\mathrm{T}_{5}$ (4.65), $\mathrm{T}_{3}$ (5.10) and $\mathrm{T}_{1} \quad(5.20)$ and significantly superior over rest of the treatments. While, minimum number of leaves per cutting (4.00) was found in control. Auxins application to the semi hardwood cuttings of guava has a significant effect on increasing the no of leaves which are one of the production sites of natural auxin in the plants beside the main activities of photosynthesis, respiration and transpiration (Wahab et al., 2001).

Maximum leaf area per cuttings $\left(24.92 \mathrm{~cm}^{2}\right)$ at 90 DAP was observed in treatment $\mathrm{T}_{1}$ (IBA $500 \mathrm{ppm}$ ), however it was at par with $\mathrm{T}_{5}$ $\left(22.02 \mathrm{~cm}^{2}\right), \mathrm{T}_{4}\left(22.80 \mathrm{~cm}^{2}\right), \mathrm{T}_{3}\left(23.83 \mathrm{~cm}^{2}\right)$ and $\mathrm{T}_{2}\left(24.45 \mathrm{~cm}^{2}\right)$ and significantly superior over rest of the treatments. While, minimum leaf area per cutting $\left(14.70 \mathrm{~cm}^{2}\right)$ was observed in control. This may be due to the fact that IBA produced healthier lengthy roots and hence absorbed more nutrients and water contents, which has resulted in higher no. of leaves produced by the plant. Similar results were reported by Bemkaireima et al., (2012) in passion fruit.

The number of sprouted cuttings at 90 DAP was maximum $\left(45.34 \%\right.$ ) in treatment $\mathrm{T}_{3}$ (IBA $1000 \mathrm{ppm}$ ), which were significantly superior over rest of the treatments. While, minimum number of sprouted cuttings $(20.62 \%)$ was observed in control i.e. $\mathrm{T}_{13}$. IBA would be effective for root initiation, sprout growth and ultimate survival of rooted cuttings of kagzi 
lime. An overall situation lead to the conclusion that, IBA at higher concentration possesses more potential in the development of roots, sprouting and decreases the mortality percentage that the control and lower concentration of IBA. (Manan et al., 2002).Similar results were reported by Manan et al., (2002) in guava and Diwaker and katiyar (2013) in Kagzi lime.

\section{References}

Anonymous, (2014) National Horticultural Production Database. MoA, GoI.

Bemkairema, K., Angami, T and Singh, M. S. (2012) Response of different size and growth regulator on cuttings of passion fruit var. Purple (Passiflora edulis var. edulis Sims). The Asian J. of Hort. 7 (2): 515-520.

Bhatt, B. B and V. Bhatt (2014) Effects of IBA and growing conditions on vegetative performance of Citrus auriantifolia Swingle cuttings. Report and Opinion: 6 (8).

Chadha, K. L. (2002) Passion fruit In: Handbook of Horticulture, Directorate of Information and Publications of Agriculture Publishers, Pusa, New Delhi.260-261.

Diwaker and P. N. Katiyar (2013) Regeneration of kagzi lime (citrus aurantifolia swingle) through stem cuttings with the aid of IBA and PHB. Hort. Flora Res. Spectrum, 2 (3): 271273.

Lima, N. P, A. A. Cunha (2001) Passion fruit: Production and Quality in Passicultura. Cruz Das Almas. Embrapa.
Manan, A., M. A. Khan., W. Ahmad and A. Sattar (2002) Clonal Propagation of Guava (Psidium guajava L.) Int. J. Agric. \& Biol. 1560-8530/04-1-143144.

Pires, M. C., J. R. Peixoto and O. K. Yamanishi (2010) Rooting of Passion Fruit Species with Indole-Butyric Acid under Intermittent Misting Condition. ISHS Acta Hort. 894:1 ${ }^{\text {st }}$ International symposium on Tropical Horticulture.

Ram, R. B., P. Kumar., A. Kumar (2005) Effect of IBA and PHB on regeneration of pomegranate (Punica granatum L.) through stem cuttings. J. New Agric. 16(1/2): 113-122.

Sanjose, A. R (1994) Passion fruit production and market. Victoria da conquista: UESB-DFZ: 41-47

Sukhjit Kaur (2015) Effect of different treatments of indole-3-butyric acid (IBA) on the rooting and growth performance of hard wood cuttings of peach (Prunus persica L. Batch). Agric. Sci. Digest, 35 (1): 41-45.

Thota, S. K. Madhavi, V. Vani and Sudha (2014) Effect of Type of Cuttings and IBA Concentrations on the Propagation of Fig (Ficus carica) cv. Poona Fig Under Open Conditions. Trends In Biosci. 7 (11): 1087-1089.

Vanderplank, J (1996) Passion flowers and Passion fruit. 2 MIT Press.

Wahab, F., G. Nabi., N. Ali and M. Shah (2001) Rooting of response semihardwood cuttings of guava (Psidium guajava L.) to various concentrations of different auxins. J. Biol. Sci. 1(4):184187.

\section{How to cite this article:}

Parse, R.N., S.B. Mane and Naglot, U.M. 2018. Studies on Effect of Chemicals on Shoot Growth Success of Cuttings in Passion Fruit (Passiflora edulis Sims). Int.J.Curr.Microbiol.App.Sci. 7(09): 3145-3151. doi: https://doi.org/10.20546/ijcmas.2018.709.392 